\title{
Efficiency of joint inoculation of soya bean by strains of Bradyrhizobium japonicum with different growth rate
}

\author{
D. Krutylo, \\ candidate of biological sciences \\ Institute of Agricultural Microbiology and Agroindustrial Manufacture of NAAS
}

The purpose. To study efficiency of joint application of strains of Bradyrhizobium japonicum with slow and intensive growth at cultivating soya bean. Methods. Microbiological, field and statistical. Results. The opportunity of use of strains of nodule bacteria of soya bean with different growth rate for increase of the yield of host plant is probed. It is determined that joint application of 2 active strains of $B$. japonicum is much more efficient as compared to monoinoculation. In binary compositions nodule bacteria with slow and intensive growth reinforce action of each other and promote formation of balanced symbiotic systems without sharp prevalence of separate strains in nodule populations. Conclusions. Composition of strains of $B$. japonicum 46 and $B$. japonicum KV11 which ensures stable increase of productivity of soya bean for $21,4-30,0 \%$ in comparison with control without inoculation is offered.

Key words: Bradyrhizobium japonicum, binary composition of strains, soya bean, Rizogumin.

Biological fixation of molecular nitrogen of the atmosphere is one of the main sources of nitrogen in agrocenoses. An important role in this process belongs to symbiotic microorganisms - nodule bacteria, which initiate the formation of nitrogen fixing nodules on the roots of legumes [1-3]. Due to the ability to fix nitrogen, nodule bacteria are considered as a valuable genetic resource for biotechnology in agriculture [4-6]. The scale of the annual production of microbial preparations for the inoculation of legumes by the areas of crops reaches hundreds of millions of hectares $[1,4,6]$.

Soils of Ukraine, during the years of soybean cultivation with the use of biopreparations, have formed and functioning populations of soybean nodule bacteria, different by density. According to our previous studies, these populations sometimes have strains that are characterized by slow and intense growth. The investigation of their biological properties showed that strains of soybean rhizobia with different growth rates have significant differences in phenotypic and genotype characteristics. It has been established that intensely grown strains actively colonize the roots of plants and are better settled down in the soil than slowly grown, that is, they are characterized by increased saprophytic competence [7]. This feature of the studied strains of nodule bacteria can be used in practice when creating new microbial preparations with a wide range of beneficial effects. A coapplication of several highly effective strains of rhizobia with a different survival strategy in the soil for inoculation of soybean seeds will contribute not only to increase the productivity of the crop, but also to form a stable, active population of specific microorganisms in the soil.

Taking into account the above, the purpose of our work was to study the effectiveness of the concomitant application of Bradyrhizobium japonicum strains with slow and intense growth for soybean cultivation.

Materials and methods of the study. The objects of the study were strains of soybean rhizobia with slow (B. japonicum 46, B. japonicum M8, B. japonicum 634b) and intensive (B. japonicum KB11 growth, and soybean varieties Ustia and KyVin.

The effectiveness of combined use of two Bradyrhizobium japonicum strains with slow and intense growth was studied in the field at the zone of Polissia of Ukraine (Institute of Agricultural Microbiology and Agroindustrial Manufacture NAAS, Chernihiv city) on the leached black soil (pHwat $-6,0$; humus content $-3,5 \%$; 
that of easily hydrolyzed nitrogen (by Kornfild) - $95 \mathrm{mg} ; \mathrm{P}_{2} \mathrm{O}_{5}-251 \mathrm{mg}$ and $\mathrm{K}_{2} \mathrm{O}$ (by Kirsanov) - $108 \mathrm{mg}$ per $1 \mathrm{~kg}$ of soil). The seeds of soybean cultivar 'Ustia' were used. When applying combined inoculation of soybean with rhizobia strains with different growth rates, they were used in a ratio of 1:1. Inoculation load was 200-300cells per 1 seed. Repetition - quadruple. Plot accounting area $-6 \mathrm{~m}^{2}$. Plot location - randomized.

During the growing season, the number and weight of the root nodules was determined. The activity of symbiotic nitrogen fixation was determined by acetylene method [8] in gas chromatograph "Chrom-4". Identification of rhizobia that infected plants was performed in the agglutination reaction using specific antiserum and nodule homogenate. The content of photosynthetic pigments in leaves of plants was measured in the flowering stage by spectrophotometry [9].

Production experiment in the conditions of central Forest Steppe of Ukraine (experimental farm "Bokhonytske" of the Institute for Feed and Agriculture of Podillia of NAAS, city of Vinnytsia) was conducted on gray forest soil ( $\mathrm{pH}-4,9-5,3$; humus content (by Turin) $-1,8-2,1 \%$; that of easily hydrolyzed nitrogen (by Kornfild) - 72,0-90,0 mg; $\mathrm{P}_{2} \mathrm{O}_{5}-100,0-120,0 \mathrm{mg}$ and $\mathrm{K}_{2} \mathrm{O}$ (by Chyrykov) - 130,0-140,0 mg per $1 \mathrm{~kg}$ of soil). A local population of nodule soybean bacteria with high density is spread in the soil. Soybean of KyVin variety was cultivated. Seeds were treated with a biopreparation of complex action by Ryzohumin on the basis of the binary composition of strains B. japonicum $46+$ B. japonicum KB11 at a rate of $200 \mathrm{~g} / \mathrm{ha}$. The area of production inspection was 25 ha.

Processing of data was performed by computer programs Microsoft Office Excel and Statistica 7.0.

Research results. In a field experiment with soybean, the competitiveness and effectiveness of $B$. japonicum strains with slow and intense growth were studied under their combined application in various combinations.

As can be seen from the data in Table 1, roots of control plants (without inoculation) showed formation of isolated nodules. Their number was insignificant (0.6-3.1 U/plant) during the entire vegetation of soybean, indicating the presence of a small population of specific nodule bacteria (population density $-10^{1}-10^{2}$ cells per $1 \mathrm{~g}$ of soil) in the soil. The serological analysis of the nodule homogenates showed that the bacteria that infected plants belong to three serological groups: KB11 (strains with intensive growth), 46 and M8 (strains with slow growth) in the ratio of $64.6 \%, 25.0 \%$, and $10,4 \%$, respectively (Table 2 ).

Despite the presence of a heterogeneous soybean rhizobia population in the soil, the application of all studied strains (B. japonicum 46, B. japonicum M8, and B. japonicum KB11) contributed to a significant 5.5- to 12.6-fold increase in the number of nodules compared to control (Table 1). Under concomitant inoculation of soybean with strains having different rates of growth, this indicator was significantly higher than with monoinoculation (1.1-2.1-folds). The maximum number of nodules was noticed in variants using two combination of slowly and intensely grown strains $-B$. japonicum $46+B$. japonicum KB11 and B. japonicum M8 + B. japonicum KB11.

1. Influence of slow and intensive-growing rhizobia strains on symbiotic parameters of soybean cultivar 'Ustia' (field experiment, IAMAM NAAS, 2014)

\begin{tabular}{|c|c|c|c|c|c|c|}
\hline \multirow{3}{*}{$\begin{array}{l}\text { Variants of the } \\
\text { experiments }\end{array}$} & \multicolumn{3}{|c|}{$\begin{array}{c}\text { Amount of } \\
\text { nodules, pieces/plant }\end{array}$} & \multicolumn{3}{|c|}{$\begin{array}{l}\text { Weight of nodules, } \\
\text { gram/plant }\end{array}$} \\
\hline & \multicolumn{6}{|c|}{ phases of growth } \\
\hline & stooling & flowering & beans filling & stooling & flowering & $\begin{array}{l}\text { beans } \\
\text { filling }\end{array}$ \\
\hline $\begin{array}{l}\text { Without inoculation } \\
\text { (control sample) }\end{array}$ & 0,58 & 1,33 & 3,08 & 0,06 & 0,10 & 0,18 \\
\hline $\begin{array}{l}\text { Inoculation with } \\
\text { B japonicum } 46\end{array}$ & 5,25 & 11,17 & 20,67 & 0,15 & 0,32 & 1,04 \\
\hline $\begin{array}{l}\text { Inoculation with } \\
\text { B japonicum M8 }\end{array}$ & 7,33 & 13,33 & 20,75 & 0,16 & 0,31 & 0,98 \\
\hline Inoculation with & 6,08 & 10,08 & 17,00 & 0,15 & 0,29 & 1,02 \\
\hline
\end{tabular}




\begin{tabular}{|c|c|c|c|c|c|c|}
\hline \multicolumn{7}{|l|}{ B. japonicum KB11 } \\
\hline $\begin{array}{l}\text { Inoculation with B. japonicum 46+ } \\
\text { B. japonicum KB11 }\end{array}$ & 10,92 & 19,75 & 24,58 & 0,23 & 0,41 & 1,21 \\
\hline $\begin{array}{l}\text { Inoculation with B. japonicum M8+ } \\
\text { B. japonicum KB11 }\end{array}$ & 11,92 & 16,08 & 25,67 & 0,24 & 0,39 & 1,16 \\
\hline $\begin{array}{l}\text { Inoculation with } B \text {. japonicum } 634 \mathrm{~b}+ \\
\text { B. japonicum KB11 }\end{array}$ & 8,42 & 10,92 & 21,00 & 0,19 & 0,36 & 1,23 \\
\hline $\mathrm{LSD}_{05}$ & 1,85 & 3,16 & 3,83 & 0,03 & 0,05 & 0,13 \\
\hline
\end{tabular}

Along with the increase in the number of nodules upon concomitant application of $B$. japonicum strains, their weight also significantly increased. The maximum values of this indicator were noted in the phase of beans swelling - 1.16-1.23 g per plant.

The results of serological analysis suggested that inoculation significantly changed the ratio of strains in the nodules (Table 2). For example, upon monoinoculation of soybean with studied strains of $B$. japonicum KB11, B. japonicum 46, and B. japonicum M8, they completely dominated in the nodules (100.0\%), displacing local rhizobia, proving the evidence of their high competitiveness.

It is noteworthy that upon the inoculation of soybean by two strains, there was no complete dominance of the introduced strains. Their share in the nodules fluctuated within $38-46 \%$. In addition, in these variants, local rhizobia also occupied their ecological niche and formed $13-17 \%$ of the nodules.

2. Competitiveness of soybean nodule bacteria with slow and intensive growth rate (field experiment, IAMAM NAAS, 2014)

\begin{tabular}{|l|c|c|c|c|}
\hline \multicolumn{1}{|c|}{$\begin{array}{c}\text { Variants of the } \\
\text { experiments }\end{array}$} & \multicolumn{3}{c|}{ \% Nodule occupancy by: } \\
\cline { 2 - 5 } & KB11 & 46 & M8 & $634 \mathrm{~b}$ \\
\hline $\begin{array}{l}\text { Without inoculation } \\
\text { (control sample) }\end{array}$ & 64,6 & 25,0 & 10,4 & 0 \\
\hline $\begin{array}{l}\text { Inoculation with } \\
\text { B japonicum 46 }\end{array}$ & 0 & 100,0 & 0 & 0 \\
\hline $\begin{array}{l}\text { Inoculation with } \\
\text { B japonicum M8 }\end{array}$ & 0 & 0 & 100,0 & 0 \\
\hline $\begin{array}{l}\text { Inoculation with } \\
\text { B. japonicum KB11 }\end{array}$ & 100,0 & 0 & 0 & 0 \\
\hline $\begin{array}{l}\text { Inoculation with B. japonicum 46+ } \\
\text { B. japonicum KB11 }\end{array}$ & 37,5 & 45,8 & 16,7 & 0 \\
\hline $\begin{array}{l}\text { Inoculation with B. japonicum M8+ } \\
\text { B. japonicum KB11 }\end{array}$ & 45,8 & 12,5 & 41,7 & 0 \\
\hline $\begin{array}{l}\text { Inoculation with B. japonicum 634b+ } \\
\text { B. japonicum KB11 }\end{array}$ & 35,4 & 8,3 & 0 & 56,3 \\
\hline
\end{tabular}

Fig. 1 shows the nitrogenase activity of the nodules upon processing soybean with strains having different growth rates. From the above data, it is seen that in the variants with inoculation with the studied nodule bacteria, the activity of symbiotic nitrogen fixation was significantly higher (2.2-7.9-fold) than in the control. As noted above, concomitant application of $B$. japonicum strains led to the highest weight of root nodules. In these variants, fixation of molecular nitrogen was the most active. In all phases of plant development, the maximum indices of nitrogen fixation activity (13.05-69.53 $\mu \mathrm{g}$ per plant per hour) was noticed upon soybean inoculation by two strains $-B$.japonicum $46+B$. japonicum KB11. 


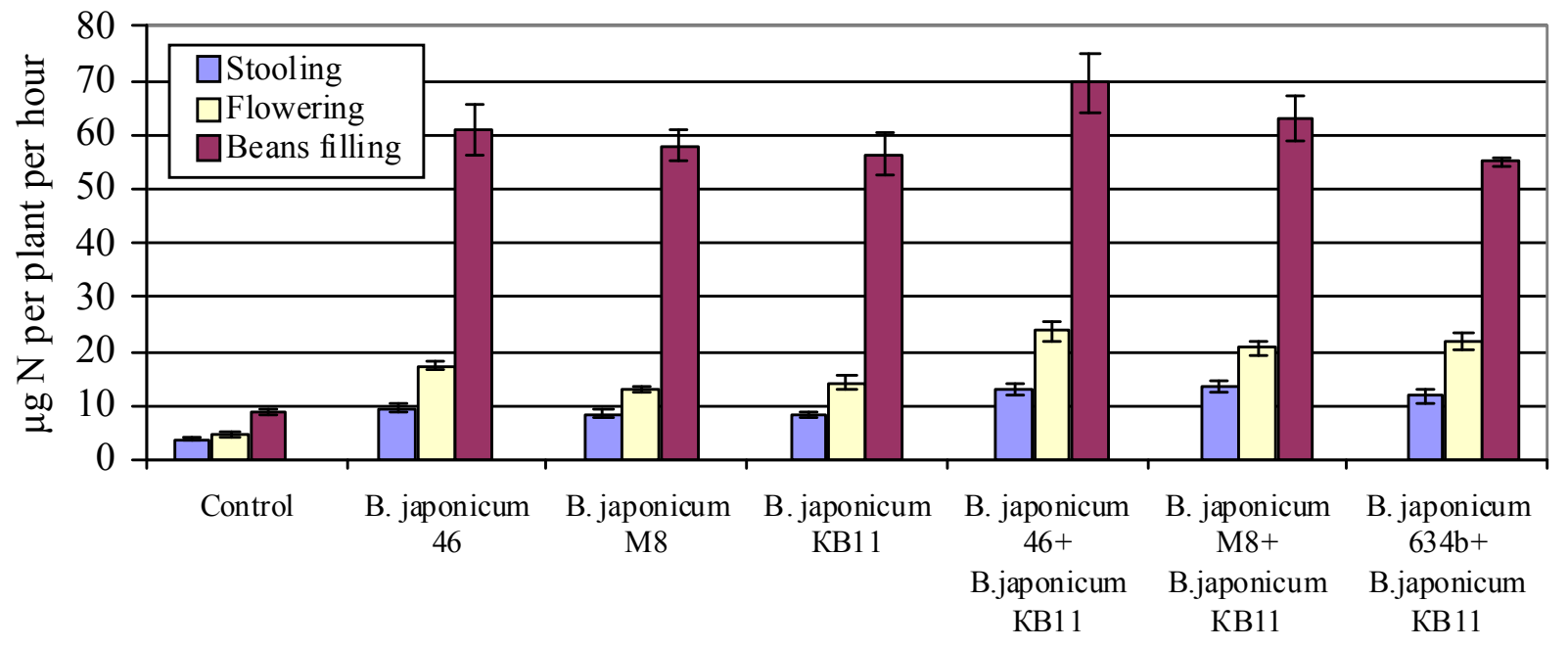

1. Activity of symbiotic nitrogen fixation under the effect of inoculation with soybean rhizobia strains with different rates of growth (field experiment, IAMAM NAAS, 2014).

The positive influence of strains of nodule bacteria on the physiological state of soybean plants is suggested by a significant increase in the content of chlorophylls $a$ and $b$ in the leaves. Thus, in variants with inoculation with individual strains of $B$. japonicum, the sum of chlorophylls $a$ and $b$ was by $18-25 \%$ higher than in the control. Upon the concomitant application of strains in all studied combinations, content of photosynthetic pigments in soybean leaves increased with respect to control by $36-40 \%$.

The activation of soybean symbiotic soybean upon inoculation with rhizobia strains with different rates of growth, contributed to a $13.0-20.5 \%$ increase in crop productivity compared with control (Table 3). Upon concomitant application of $B$. japonicum strains, they intensified action of each other, soybean yield gain reached $16.7-27.6 \%$.

The generalized results of many years of field experiments indicate the stability of action of the compositions of $B$. japonicum strains with different growth rates. On average, over three years, the highest yield of soybean was obtained using the concomitant application of strains B. japonicum 46 and B. japonicum KB11-3.02 t/ha vs. $2.39 \mathrm{t} / \mathrm{ha}$ in control without inoculation.

3. Seed productivity of soybean of variety Ustia under the effect of combined inoculation with slowly and intensely growing strains of rhizobia (field experiments, IAMAM NAAS, 2012-2014)

\begin{tabular}{|c|c|c|c|c|c|c|c|}
\hline \multirow[b]{2}{*}{$\begin{array}{l}\text { Variants of the } \\
\text { experiments }\end{array}$} & \multicolumn{5}{|c|}{ Yield, tons/ha } & \multirow{2}{*}{\multicolumn{2}{|c|}{$\begin{array}{l}\text { Increment, } \\
\%\end{array}$}} \\
\hline & 2012 & 2013 & 2014 & Average & $\begin{array}{c}\text { Average on } \\
\text { mono- and }\end{array}$ & & \\
\hline $\begin{array}{l}\text { Without inoculation } \\
\text { (control sample) }\end{array}$ & 2,55 & 2,23 & 2,39 & 2,39 & 2,39 & - & - \\
\hline $\begin{array}{l}\text { Inoculation with } \\
\text { B japonicum } 46\end{array}$ & 2,96 & 2,61 & 2,83 & 2,80 & \multirow{3}{*}{2,76} & $+17,2$ & \multirow{3}{*}{15,4} \\
\hline $\begin{array}{l}\text { Inoculation with } \\
\text { B japonicum M8 }\end{array}$ & 2,88 & 2,53 & 2,70 & 2,70 & & $+13,0$ & \\
\hline $\begin{array}{l}\text { Inoculation with } \\
\text { B. japonicum KB11 }\end{array}$ & 2,88 & 2,55 & 2,88 & 2,77 & & $+15,9$ & \\
\hline $\begin{array}{l}\text { Inoculation with B. japonicum 46+ } \\
\text { B. japonicum KB11 }\end{array}$ & 3,10 & 2,90 & 3,05 & 3,02 & 2,91 & $+26,4$ & 21,8 \\
\hline
\end{tabular}




\begin{tabular}{|l|c|c|c|c|c|c|}
\hline $\begin{array}{l}\text { Inoculation with } B \text {. japonicum M8+ } \\
\text { B. japonicum KB11 }\end{array}$ & 3,04 & 2,72 & 3,01 & 2,92 & & $+22,2$ \\
\cline { 1 - 1 } $\begin{array}{l}\text { Inoculation with B. japonicum 634b+ } \\
\text { B. japonicum KB11 }\end{array}$ & 2,97 & 2,64 & 2,75 & 2,79 & & $+16,7$ \\
\hline $\mathrm{LSD}_{05}$ & 0,12 & 0,18 & 0,19 & & & \\
\hline
\end{tabular}

Analyzing the results of the serological study of the nodules during three years and the yield data, it can be noted that the dominance in the nodule populations of certain active strains with different growth rates is not essential for the formation and functioning of effective symbiosis. In our opinion, formation of a balanced symbiotic soybean system with several complementary, although serologically different strains of rhizobia of one species is more important.

The binary composition of $B$. japonicum $46+B$. japonicum KB11 strains as a basis for the microbial preparation Ryzohumin was tested in a production experiment in the soil-climatic conditions of the central forest steppe of Ukraine.

It was established that in the presence of a dense local population of specific nodule bacteria in the soil, the studied biopreparation provided a significant increase in the yield of soybean variety KyVin by $21.4 \%$ compared to the control without inoculation (Tabl 4).

The binary composition of Bradyrhizobium japonicum strains with different growth rates is protected by the Ukrainian patent, and it is recommended to use it to increase the yield of soybean and to create an active population of specific nodule bacteria in the soil [10].

4. Efficiency of Ryzohumin based on the binary composition of B. japonicum strains upon cultivation of soybean variety KyVin (production experiment, 2014, IFAP NAAS)

\begin{tabular}{|c|c|c|}
\hline $\begin{array}{c}\text { Variants of the } \\
\text { experiments }\end{array}$ & Yield, tons/ha & Increment, \% \\
\hline $\begin{array}{c}\text { Without inoculation } \\
\text { (control sample) }\end{array}$ & 2,01 & 21,4 \\
\hline $\begin{array}{l}\text { Ryzohumin (B. japonicum 46+ } \\
\text { B. japonicum KB11) }\end{array}$ & 2,44 & \\
\hline
\end{tabular}

\section{Conclusions}

It was established that the concomitant application of two active strains of $B$. japonicum with different growth rates predominates monoinoculation in terms of efficiency. In binary compositions, rhizobia with a slow and intense growth intensify the action of each other and contribute to the formation of balanced symbiotic systems without the sharp dominance of individual strains in the nodule populations.

On average, over three years, the highest yield of soybean was obtained using the concomitant application of strains B. japonicum 46 and B. japonicum KB11 - 3.02 t/ha vs. 2.39 t/ha in control without inoculation. Treatment of soybean seeds with a biopreparation Ryzohumin on the basis of this composition of strains provided a $21.4 \%$ increase in crop yield compared to control without inoculation.

\section{References}

1. Rhizobiaceae. Molekuljarnaja biologija bakterij, vzaimodejstvujushhih s rastenijami / pod red. Spajnka G., Kondoroshi A., Hukasa P. Per. s angl. S-Pb.: Biont, 2002. - 558 s.

2. Zahran H.H. Rhizobia from wild legum: diversity, taxonomy, ecology, nitrogen fixation and biotechnology / H.H. Zahran // J. Biotechnol. - 2001. - V. 91. - № 2-3. - P. 143-153.

3. Giles E.D.O. Coordinating nodule morphogenesis with rhizobial infection in Legumes / E.D.O. Giles, J.A. Downie // Annu. Rev. Plant Biol. - 2008. - Vol. 59. - P. 519-546.

4. Bioregulyatsiya mikrobno-rastitelnyih sistem: monogr. / [lutinskaya G.A., Ponomarenko S.P., Andreyuk E.I. i dr.]; pod red. G.A. lutinskoy, S.P. Ponomarenko. - K.: Nichlava, 2010. - 464 s. 
5. Koc' S.Ja. Biologicheskaja fiksacija azota: bobovo-rizobial'nyj simbioz / S.Ja. Koc', V.V. Morgun, V.F. Patyka i dr. - T. 2 . - K.: Logos, 2011. - 523 s.

6. Sidorova K.K. Simbiogenetika i selektsiya makrosimbionta na povyishenie azotfiksatsii na primere goroha (Pisum Sativum L.) / K.K. Sidorova, V.K. Shumnyiy, E.Yu. Vlasova i dr. // Vestn. VOGiS. - 2010. - T. 14. N 2. - S. 357-374.

7. Krutylo D.V. Biologichna riznomanitnist' bul'bochkovyh bakterij soi' v g'runtah Ukrai'ny / D.V. Krutylo, O.V. Nadkernychna, T.M. Kovalevs'ka, V.P. Patyka // Mikrobiol. zhurn. - 2008. - T. 70, - № 6. - S. 27-34.

8. Hardy R.W.F. The acetylene-ethylene assay for N2-fixation: Laboratory and field evaluation / R.W.F. Hardy, R.D. Holsten, E.K. Jackson, R.C. Burns // Plant Physiol. - 1968. - V. 43, - №8. - P. 1185-1207.

9. Grodzinskij A.M. Kratkij spravochnik po fiziologii rastenij / A.M. Grodzinskij, D.M. Grodzinskij. - K.: Naukova dumka, 1973. - $398 \mathrm{~s}$.

10. Pat. 111340 Ukrai'na, MPK S12N 1/20, S05F 11/08. Binarna kompozycija shtamiv Bradyrhizobium japonicum z riznoju shvydkistju rostu dlja pidvyshhennja produktyvnosti soi' / Krutylo D.V.; zajavnyk ta patentovlasnyk In-t s.-g. mikrobiologii' ta agropromyslovogo vyrobnyctva NAAN. - № u 2016 04110; zajavl. 15.04.16; opubl. 10.11.16, Bjul. № 21. - $6 \mathrm{~s}$. 